\title{
Relationship between Need for Belongingness and Facebook Addiction: Mediating Role of Number of Friends on Facebook
}

\author{
Umme Kulsuma Rashid $^{1}$, Oli Ahmed ${ }^{1} \&$ Muhammad Alamgir Hossain $^{2}$ \\ ${ }^{1}$ Lecturer, Department of Psychology, University of Chittagong, Chittagong-4331, Bangladesh \\ ${ }^{2}$ Assistant Professor, Department of Psychology, University of Chittagong, Chittagong-4331, Bangladesh \\ Correspondence: Umme Kulsuma Rashid, Lecturer, Department of Psychology, University of Chittagong, \\ Chittagong-4331, Bangladesh.
}

Received: December 17, 2018

Accepted: January 23, 2019 Available online: February 1, 2019

doi:10.11114/ijsss.v7i2.4017

URL: https://doi.org/10.11114/ijsss.v7i2.4017

\begin{abstract}
As humans, we need to connect with one another, our friends and families, our culture and country. Present age is the era of information and technology and social media. College and University students spend significant amount of time on Social Networking Sites like Facebook etc. The present study was conducted to explore role of number of friends on Facebook on the relationship between individual's need for belongingness and Facebook addiction. A sample of 180 university students was selected as sample through the non-probability sampling technique. Findings suggested that male Facebook users had significantly higher number of friends on Facebook than female Facebook users. Findings also explored significant positive correlation among need for belongingness, number friends on Facebook, and Facebook addiction. The relationship between need for belongingness and Facebook addiction was partially mediated by number of friends on Facebook. The study findings would be helpful to mental health practitioners to effectively deal with emerging problem of Facebook addiction.
\end{abstract}

Keywords: Facebook, belongingness, Facebook friends, Facebook addiction

\section{Introduction}

We all are inclined to establish and also retain personal and strong relationships in long-term (Baumeister \& Leary, 1995). Belongingness, as a need, is introduced in the Maslow's (1968) hierarchy model of motivation that suggests that we have a need to feel a sense of belonging and acceptance among social groups. In this hierarchical model, belongingness need will be met after fulfilling physiological and safety needs for pursuing esteem and self-actualization. Kohut (1984) elaborated by viewing this need as an independent need. Later, this concept was expanded by Lee and Robbins (1995). They described belongingness as how people "pursue to confirm a subjective sense of belongingness or being a part of in order to escape from feelings of loneliness and alienation". They divided this need into companionship, connectedness, and affiliation components (Lee \& Robbins, 1995). Companionship, first component, starts in early infancy periods. It is contended by persons who are passing a great amount of time with a child closely mainly parent (Lee \& Robbins, 1995). Companionship can increase the leisure participation, decrease the feeling of loneliness, and also predict social satisfaction, well-being, etc (Baldassare, Rosenfield, \& Rook, 1984; Unger, 1984; Rook, 1987). Affiliation, second component, is the identifying oneself in a group. It is important in adolescence period when relationships with peer groups become one of the central areas of focus in the path of development (Kohut, 1984). Social connectedness, third component, can be defined as one's subjective awareness to be in the close relationship with significant others in our social world (Lee \& Robbins, 1995). For belongingness drive, people always try to connect with other people. People are now connecting both offline and online others through various Social Networking Sites (SNSs). Universality of SNSs has spread widely, and usage of SNSs has increased the scope of friendship facilitation over the past 15 years (Palfrey \& Gasser, 2008).

Present age is the time of facts, technology and social media. Social media are generally defined as forms of electronic communication where users can create communities to share information, ideas, pictures, videos and other content. Social networking sites are a subcategory of social media, which generally entail the creation and maintenance of online relationships both personal and professional via various platforms (Schauer, 2015). The leading platforms of SNS are Facebook, Twitter, Instagram, Snapchat, etc. 
Facebook is perhaps the largest social media platform ever, reaching nearly $80 \%$ of all people on the internet. At the beginning of 2017, Facebook reported that the number of users who visited Facebook every day reached 1.23 billion, an $18 \%$ year-over-year increase. Facebook's monthly active users also experienced a $17 \%$ year-over-year increase, reaching over 1.86 billion. Social networking sites - most notably Facebook - have had a strong impact on how friendships are mediated in today's world SNS may work as a major field through which young adults arrange valuable tasks, including personality development and protecting important relationships (Moreno \& Whitehill, 2014).

In college and university, the usage of SNSs gets huge attention due to the educational emphasis on technology, research, and training (Dede, 2013). In addition, college and university students are cited as the most frequent SNS users as they use it for both social and information gathering purposes (Martínez-Alemán, 2014). Current students are the most prolific technology user generation. Their identity development through social interactions is one of the primary concerns (Arnett, 2000). In College and university period, students are in intensive life transition. They face a variety of changes in this transition period (i.e., new living environments, academic expectations, friendship networks, etc.) (Pittman \& Richmond, 2008). There are huge risks to be addicted on Facebook. According to the Pew Research Center, 92\% Internet users, aged from 18 to 29 , use social networking sites (Perrin, 2015). SNS use has been found to contribute to positive psychosocial well-being and sense of community (Henry, 2012), increased self-esteem (Gonzales \& Hancock, 2011), increased social capital (Ellison, Steinfield, \& Lampe, 2011), increased life satisfaction (Bargh \& McKenna, 2004), facilitation of off-line social interactions (Jacobsen \& Forste, 2011), and facilitation of a higher quantity as well as quality of friendships (Mihailidis, 2014). Although Facebook could be a significant gadget to connect with friends, there is a line that could be crossed in which adolescents utilize Facebook too much where they pass the border from simply using the site to devoting all of their time to inspecting their news feeds. Excessive use as well as ease of its use makes many adolescents addicted to it.

Dependence upon ingested substances is considered as addiction (Brenner, 1997). Behavior researchers suggested the possibility to develop behavior related addiction (Griffiths, 1996; Brown, 1997). Internet addiction is one kind of behavior addiction (Griffiths, 1999). Facebook addiction is one type of internet addiction. Facebook addiction can be defined as spending an excessive amount of time on Facebook. Normally, spending much time on Facebook interferes with many vital activities of a person's life (Toma, 2011). Excessive use of Facebook is causing for different psychological and social problems such as depression, anxiety, loneliness, and poor real life social interaction. Rahman and Ahmed (2108) suggested Facebook use and addiction as negative predictors toward the users' mental health. Summers (2011) suggested six symptoms of Facebook Addiction. These are - detrimental effect desperate behaviors of a Facebook addicted person on his daily life, signs of anxiety, distress, unrest while difficulty in using Facebook for participating in daily activities, reduction of normal social and recreational activities, virtual dates, a good number of fake friends, and total dependency on Facebook in daily activities. Ahmed (2018) Facebook timeline browsing decreases the mental health of users.

Helliwell and Huang (2013) conducted a study comparing how offline friends and facebook friends affect our levels of well-being. They found that only real life friends had a significant positive effect on well-being. Doubling the number of Facebook friends was equivalent to a $10 \%$ decrease in income levels. Negative effects of having a higher number of Facebook friends on well-being were particularly higher for middle-aged females in the sample. (Ellison et al., 2007).

Moody (2001) also showed that increased use of the internet (e.g., time spent on Facebook) was associated with a higher degree of emotional loneliness (e.g., absence of intimate relationships), suggesting that the relationships established over the Internet did not meet the social connection needs of individuals and were even capable of inducing depressive states. Zaremohzzabieh, Samah, Omar, Bolong, \& Kamarudin (2014) reported that the overuse of sites can become disruptive to daily life or lead to negative outcome such as loneliness, depression, anxiety, and phobias. Excessive Facebook use has been found to harm psychological and social well-being of individuals and their personality (Harzadin, 2012).

Study suggested positive relationship between use of online social networks and belongingness (James, Lowry, Wallace, \& Warkentin, 2017). This study also suggested that belongingness in OSNs decreases the OSNs envy and anxiety, and slightly increases the OSN fear of missing out. However, belongingness is not same for everyone. Introverted people, having a Facebook account, have lower level of belongingness than extrovert people (Stronge et al., 2015). This varied amount of belongingness also influences the usage of Facebook. Study suggested that connection and disconnection both are increased by Facebook use (Sheldon, Abad, \& Hinsch, 2011). However, connectedness goes away after time spent away from Facebook, whereas feelings of disconnection persisted and drove further Facebook use. Facebook use may negatively affect belongingness feelings of introverted people. Because introverted people had low levels of belonging overall and tend to be less active on Facebook than their extroverted people (Ryan \& Xenos, 2011). Tüfekçi's (2008) found that females tend to use social networks to keep in touch with friends while males tend to use social networks to find friends of same personality. Thelwall (2008) and Lenhart \& Madden (2007) found that males are more 
likely to make new relationship more than females do. Similarly, comparisons of different social networking systems in terms of demographics such as gender, frequency of use remain as the most popular research areas. There is not adequate research connecting belongingness with number of facebook friends. Unfortunately, no proper attention has been given to such serious issue like Facebook addiction in Bangladesh. Moreover, not much research seems to have been done on the Facebook addiction in Bangladesh context.

Through this study, authors tried to find out the answer of the questions - was there any relationship individual's need for belongingness and Facebook addiction. If any, what would be the role of number of friends on Facebook? Main objective of the study was to examine the relationship between need for belongingness and Facebook addiction, and role of the number of friends on Facebook in this relationship. The specific objectives were- i) to assess the mean differences in need for belongingness score, number of friends on Facebook, and Facebook addiction; ii) to assess the relationship among need for belongingness score, number of friends on Facebook, and Facebook addiction; iii) to explore the role of gender among the relationship of this variables.

\section{Method}

\section{Participants}

The target population of the present study was Bangladeshi young. Accessible population of the present study was students from colleges and universities of Bangladesh. Among colleges and universities, one college from the Dhaka city and the University of Chittagong were selected through convenience sampling technique. Among these two educational institutions, 180 students were selected as sample through the purposive sampling technique. Students, who were active user and using Facebook more than one year, selected as study sample. Their age mean was 21.25 years and standard deviation was 2.43 years. Table 1 shows the respondnets' distribution.

Table 1. Sample distribution of the present study

\begin{tabular}{|c|c|c|c|c|}
\hline & \multicolumn{2}{|c|}{ Educational Institution } & \multicolumn{2}{|c|}{ Residence } \\
\hline & College & University & Urban & Rural \\
\hline Male & $38(21.1 \%)$ & $74(41.1 \%)$ & $67(37.2 \%)$ & $45(25.0 \%)$ \\
\hline Female & $5(2.8 \%)$ & $63(35.0 \%)$ & $54(30.0 \%)$ & $14(7.8 \%)$ \\
\hline Total & $43(23.9 \%)$ & $137(76.1 \%)$ & $121(67.2 \%)$ & $59(32.8 \%)$ \\
\hline
\end{tabular}

\section{Measures}

In the present study, the Bangla (Ahmed \& Hossain, 2018) Need to Belong Scale (Leary, Kelly, Cottrell, \& Schreindorfer, 2013), and the Bangla (Ahmed \& Hossain, 2018) Bergen Facebook Addiction Scale (BFAS: Andreassen, Torsheim, Brunborg, \& Pallesen, 2012) were used to collect information about respondents' feelings about need to belong, and Facebook addiction. Along with these measures, respondents were asked about number friends on Facebook friend list.

Bergen Facebook Addiction Scale (BFAS): The BFAS is a 6 items measure. Its 6 items reflect the six core elements of addiction i.e. salience, tolerance, relapse, mood modification, conflict, withdrawal. Respondents were required to express their opinion regarding Facebook addiction through using a 5-point Likert type scale $(1=$ very rarely to $5=$ very often). Total score ranged from 6 to 30. Higher scores indicated higher level of addiction. The BFAS is a psychometrically sound measure that could be used in clinical settings also. The Cronbach's Alpha of the this measure in the original study was .83. Item-total correlations were ranged from $.60-.73$ and test-retest reliability was .82 as reported by authors. This measure was highly correlated with the Addictive Tendencies Scale (Willson, Fornaseir, \& White, 2010) and the Facebook Attitude Scale (Ellison, Steinfield, \& Lampe, 2007). The Bangla BFAS is psychometrically sound measure. The score above 19 in the Bangla BFAS indicated addiction on Facebook. The Cronbach's Alpha of the BFAS in the present study was .720 (95\% CI [.652, .779]).

Need to Belong Scale: The Need to Belong is a 10 item measure that measure individual's need for connectedness with others. It a 5-point Likert type scale $(1=$ strongly disagree to $5=$ strongly agree). Total score ranged from 10 to 50 . Higher scores indicated higher need for belongingness. It is a psychometrically sound measure as reported by authors. The Chronbach's Alpha across sample ranged from .78 to .87 . Test-retest reliability was .87 within a gap of 10 weeks. The Cronbach's Alpha of this scale in the present study was .941 (95\% CI [.928, .935]).

\section{Procedure}

The questionnaire method was used to collect data in the present study. A questionnaire, contained the above mentioned scales, questions, a demographic information form and instructions sheet, was given to the selected participants. The study purposes and its importance were explained to the participant both in instruction sheet and verbally. Confidentiality of their responses was also assured. 


\section{Results}

\section{Data Characteristics}

The residual in regression analysis was applied to assess the normality of the data. The skewness [.241(.180)] and kurtosis statistics [-.371 (.358)], Kolmogorov-Smirnov ( $H=.06, p>.200)$, and Shapiro-Wilk test $(w=.99, p>.05)$ suggested that the data were nearly normal. The Breusch-Pagan [4.73 (.09)] and Koenker [5.56 (.06)] tests statistics suggested the homoskedasticity of the data.

\section{Final Analysis}

The data were analyzed to estimate the descriptive statistics (mean and standard deviation) of need for belongingness score, number of friends on Facebook, and Facebook addiction score. The obtained results of the analysis are presented in the Table 2.

Table 2. Descriptive statistics of need for belongingness, number of friends on Facebook, and Facebook addiction

\begin{tabular}{|c|c|c|c|c|c|c|}
\hline \multirow[t]{2}{*}{ Variable } & \multirow[t]{2}{*}{ Mean } & \multirow[t]{2}{*}{$\begin{array}{l}\text { Standard } \\
\text { Deviation }\end{array}$} & \multirow[t]{2}{*}{ Minimum } & \multirow[t]{2}{*}{ Maximum } & \multicolumn{2}{|c|}{$\begin{array}{l}95 \% \text { Confidence Interval } \\
\text { for Mean }\end{array}$} \\
\hline & & & & & Lower & Upper \\
\hline Need for Belongingness & 30.13 & 11.02 & 10 & 46 & 28.51 & 31.76 \\
\hline Friends on Facebook & 736.91 & 542.96 & 75 & 2300 & 657.05 & 816.77 \\
\hline Facebook Addiction & 14.17 & 4.72 & 6 & 28 & 13.47 & 14.86 \\
\hline
\end{tabular}

The collected data were subjected to the 'independent sample t-test' to assess the mean differences in need for belongingness score, number of friends on Facebook, and Facebook addiction score by respondents' gender. Results are presented in Table 3.

Table 3. Mean differences in need for belongingness, number of friends on Facebook, Facebook addiction by gender (male $=112$, female $=68)$

\begin{tabular}{|c|c|c|c|c|c|c|c|c|}
\hline \multirow[t]{2}{*}{ Variable } & \multicolumn{2}{|c|}{ Male } & \multicolumn{2}{|c|}{ Female } & \multirow[t]{2}{*}{$t(d f=178)$} & \multicolumn{2}{|c|}{$95 \%$ confidence interval } & \multirow[t]{2}{*}{$d$} \\
\hline & $M$ & $S D$ & $M$ & $S D$ & & Lower & Upper & \\
\hline $\mathrm{NfB}$ & 29.74 & 11.06 & 30.78 & 11.02 & -.61 & -4.39 & 2.31 & -.09 \\
\hline $\mathrm{FoF}$ & 808 & 554 & 619 & 506 & $2.28 *$ & 82.51 & 351.02 & .35 \\
\hline FA & 13.82 & 4.35 & 14.74 & 5.28 & -1.26 & -2.35 & .51 & -.20 \\
\hline
\end{tabular}

$* p<.05, \mathrm{NfB}=$ Need for Belongingness, NFF = Number of Friends on Facebook, FA= Facebook Addiction, $d=$ effect size

Table 3 shows significant gender differences in number of friends on Facebook $(t$-value $=2.28, p<.05,95 \%$ CI $[82.51$, $351.02], d=.35$ ).

The collected data were subjected to the Pearson product moment correlation coefficient to estimate the correlations among need for belongingness, number of friends on Facebook, and Facebook addiction. Results are presented in Table 4.

Table 4. Correlation coefficient among need for belongingness, number of friends on Facebook, and Facebook addiction

\begin{tabular}{|c|c|c|}
\hline Variables & Need for Belongingness & Number of Friends \\
\hline Number of Friends & $.454 * * *[.330, .563]$ & \\
\hline Facebook Addiction & $.520 * * *[.444, .648]$ & $.555 * * *[.444, .648]$ \\
\hline
\end{tabular}

Facebook Addiction $520 * * *[.444, .648]$

Table 4 shows that need for belongingness significantly correlated with number friends on Facebook $(r=.454, p<.001,95 \%$ $C I[.330, .563])$, and Facebook addiction $(r=.520, p<.001,95 \% C I[.444, .648])$.

The collected data were analyzed by the process analysis (Hayes, 2013) to test the mediating role of number of Facebook friends on the relationship between need for belongingness and Facebook addiction. Results of the process analysis (Model 4) are presented in Table 5.

Table 5. Results of the process analysis

\begin{tabular}{|c|c|c|c|c|c|c|c|c|}
\hline \multirow[t]{3}{*}{ Antecedent } & \multicolumn{8}{|c|}{ Consequent } \\
\hline & \multicolumn{4}{|c|}{ NFF(M) } & \multicolumn{4}{|c|}{ FA (Y) } \\
\hline & B & $S E$ & $L L C I$ & $U L C I$ & B & $\overline{S E}$ & $L L C I$ & ULCI \\
\hline NfB (X) & $22.35 * *$ & 3.29 & 15.87 & 28.85 & $.16^{* *}$ & .03 & .09 & .20 \\
\hline NFF (M) & & & & & $.005 * *$ & .001 & .002 & .005 \\
\hline \multirow[t]{2}{*}{ Constant } & 63.16 & 105.50 & -145.03 & 271.35 & \multirow{2}{*}{\multicolumn{4}{|c|}{$R^{2}=.398, F(2,177)=58.59, p<.001, f^{2}=.66$}} \\
\hline & \multicolumn{4}{|c|}{$R^{2}=.21, F(1,178)=46.21, p<.001, f^{2}=.27$} & & & & \\
\hline \multicolumn{9}{|c|}{ Indirect effect of NfB on FA: $(B=.078, S E=.017, p<.01,95 \% C I$ of $B[.045, .116])$} \\
\hline \multicolumn{9}{|c|}{$\begin{array}{l}* * p<.01, \mathrm{X}=\text { independent variable, } \mathrm{M}=\text { mediator variable, } \mathrm{Y}=\text { dependent variable, } B=\text { unstandardized Beta, } S E=\text { standard error } \\
L L C I=\text { lower limit of } 95 \% \text { confidence interval, } U C L I=\text { upper limit of } 95 \% \text { confidence interval, } N f B=\text { Need for Belongingness, } N F I \\
=\text { Number of Facebook Friends, } F A=\text { Facebook Addiction, } f^{2}=\text { effect size }\end{array}$} \\
\hline
\end{tabular}


$C I$ of $B[.09, .20])$ that mediated by the number of Facebook friends $(B=.05, S E=.001, p<.01,95 \% C I$ of $B[.002, .005])$. To get graphical picture of such relationship among these variables, results are presented in Figure 1.

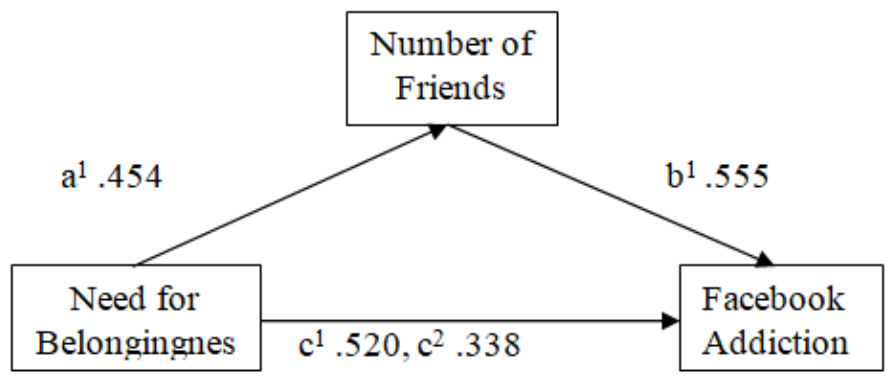

Figure 1: $\mathrm{a}^{1}$ denotes direct effect of need for belongingness on number of Facebook friends $(\beta=.454), \mathrm{b}^{1}$ denotes for direct effect of number of Facebook friends on Facebook addiction $(\beta=.555), \mathrm{c}^{1}$ denotes for direct effect of need for belongingness on Facebook addiction $(\beta=.520)$, and $c^{2}$ denotes for mediating effect of the need for belongingness on Facebook addiction $(\beta=.338)$. Indirect effect of the need for belongingness on Facebook addiction was .252.

The collected data were subjected to analysis of covariance to assess the effect of gender on Facebook addiction after the effect of need for belongingness and number of Facebook friends. Results are presented in Table 6.

Table 6. Test statistics of analysis of covariance

\begin{tabular}{lrrrrr}
\hline Source & Type III Sum of Squares & Df & Mean Square & \multicolumn{1}{c}{$\begin{array}{c}\text { Partial Eta } \\
\text { Squared }\end{array}$} \\
\hline Corrected Model & 1683.29 & 3 & 561.10 & $42.61 * * *$ & .421 \\
Intercept & 1162.45 & 1 & 1162.45 & $88.27 * * *$ & .334 \\
NfB & 307.89 & 1 & 307.89 & $23.38^{* * *}$ & .117 \\
NFF & 581.06 & 1 & 581.06 & $44.12^{* * *}$ & .200 \\
Gender & 89.64 & 1 & 89.64 & $6.81 * *$ & .037 \\
Error & 2317.71 & 176 & 13.17 & \\
Total & 40126.00 & 180 & & \\
Corrected Total & 4001.00 & 179 & & \\
\hline$* * p<01, * * * p<.001$ & & &
\end{tabular}

$* * p<.01, * * * p<.001$

Table 6 shows that effect of significant effect of gender $(F=6.81, p<.01)$, number of Facebook friends $(F=44.12, p<.001)$, and need for belongingness $(F=23.38, p<.001)$ on Facebook addiction. Need for belongingness explained $11.7 \%$ variance of Facebook addiction while controlling number of Facebook friends and gender. Number of Facebook friends explained $20 \%$ variances while controlling other two variables and gender explained 3.7\% variance while controlling need for belongingness and number of Facebook friends. Gender, Need for belongingness, and number of Facebook friends explained $42.1 \%$ variances of Facebook addiction.

\section{Discussion}

The mediating role of the number of Friends on Facebook in the relationship between individual's need for belongingness and Facebook addiction was investigated in the present study. Table 3 showed significant gender differences in number of friends on Facebook. Rana, Ahmed, and Hossain (2016) conducted a study on a sample of 141 Facebook users and found male had more friends on Facebook than female. Finding regarding non-significant gender differences in Facebook addiction was also consistent with the study of Rana et al. (2016). Male students had more friends on Facebook than female students. Study suggested that female are using Facebook for maintaining existing relationships, academic purposes, etc. and male use Facebook for making new relationships (Mazman \& Usluel, 2011). This study also suggested that the rate of making new friends on Facebook is higher for male than female. Males use SNSs mostly for making new friends and relationships. Females use it mostly for finding their old friends and keeping in touch with the existing ones.

Table 4 showed significant correlation among need for belongingness, number of Facebook friends, and Facebook addiction. Results from Table 5 and Figure 1 suggested that the relationship between need for belongingness and Facebook addiction partially mediated by number of friends on Facebook. Both need for belongingness and number of friends on Facebook explained 39.8\% variability of Facebook addiction. Table 6 showed that need for belongingness explained 11.7\% variance, number of Facebook friends explained 20\%, and gender explained 3.7\% variance while controlling others two factors. Gao, Liu, and $\mathrm{Li}$ (2017) found mediated relationship between sense of belonging and SNS addiction. In their study, this relationship mediated by enjoyment and escapism. Study suggested higher level of Facebook use was related to higher level of friend sickness (Klingensmith, 2010). Social recognition, social acceptance, etc., are 
universal human need. Having friends validates our boosts our self-esteem. SNSs like Facebook, etc., are becoming virtual form of real life social connections. So, there is also a demand of belongingness with others surrounding us in virtual world. Study suggested that belongingness influence one's knowledge sharing behavior (Chai \& Kim, 2012). Such accumulate Facebook friends that could be lead to the excessive use of Facebook and dependency on it. However, number of friends on Facebook suggests nothing about the depth of the relationships. Social capital theory suggested that social support through online influenced SNSs addiction (Yang, Liu, \& Wei, 2012). Facebook makes it easy to keep touch with the family and significant others whatever they are staying currently. One can inform about the updates of family and significant others immediately they post in Facebook. Even, one can contact with them very quickly.

However, younger generations seem to prefer isolation and they seem to be in their own imaginary world rather than with real life friends and family (Subramanian, 2017). This feeling of isolation might also lead to higher level of belongingness. When one has insufficient social contact with significant others, loneliness feeling is normal. He seeks out significant others. In such cases a Facebook user can get a quick relief from the feeling of loneliness through interacting with others through Facebook. However, spending more time on Facebook to reduce loneliness may contribute to more feeling of loneliness, and lead to depression in some situations.

\section{Limitations and Recommendations}

In spite of numerous contributions, this study is not without limitations. Participants were sampled on the basis of certain age group which indicates the need for conducting this research on different age group. More sophisticated statistical analysis could be used by including other related variables e.g., Loneliness, Emotional support to determine different possible significant predictors of Facebook addiction. In this study, we address the addiction on Facebook only, not other SNSs. It is another major limitation of this study. Future study would be taken to clarify the role of need for belongingness and number of virtual friends through SNSs on addiction on different SNSs.

\section{References}

Ahmed, O. (2018). Relationship between Loneliness and Mental Health among First- Year Undergraduate Students: Mediating role of Timeline Browsing and Chatting on Facebook. International Journal of Contemporary Education, 1(2), 81-89. https://doi.org/10.11114/ijce.v1i2.3625

Ahmed, O., \& Hossain, M. A. (2018). The Validation study of the Need to Belong Scale. Unpublished Manuscript. Department of Psychology: University of Chittagong.

Ahmed, O., \& Hossain, M. A. (2018). Validation study of the Bergen Facebook Addiction Scale a Sample of a Bangladeshi People. Journal of Addcition Research \& Therapy, 9(5). https://doi.org/10.4172/2155-6105.1000369

Andreassen, C. S., Torsheim, T., Brunborg, G. S., \& Pallensen, S. (2012). Development of a Facebook Addiction Scale. Psychological Reports, 110(2), 501-517. https://doi.org/10.2466/02.09.18.PR0.110.2.501-517

Arnett, J. J. (2000). Emerging adulthood: A theory of development from the late teens through the twenties. American Psychologist, 55(5), 469-480. https://doi.org/10.1037/0003-066X.55.5.469

Baldassare, M., Rosenfield, S., \& Rook, K. S. (1984). The types of social relations predicting elderly well-being. Research on Aging, 6(4), 549-559. https://doi.org/10.1177/0164027584006004006

Bargh, J. A., \& McKenna, K. Y. (2004). The Internet and social life. Annual Review of Psychology, 55, 573-590. https://doi.org/10.1146/annurev.psych.55.090902.141922

Baumeister, R. F., \& Leary, M. R. (1995). The need to belong: Desire for interpersonal attachments as a fundamental human motivation. Psychological Bulletin, 117(3), 497-529. https://doi.org/10.1037/0033-2909.117.3.497

Biernatowska, A., Balcerowska, J. M., \& Bereznowski, P. (2017). Gender differences in using Facebook—preliminary analysis. In J. Nyćkowiak \& J. Leśny (Eds.), Badania i Rozwój Młodych Naukowców w Polsce - Społeczeństwo: psychologia i socjologia (pp. 13-18). Poznań, Poland: Młodzi Naukowcy.

Brenner, V. (1997). Psychology of Computer Use: XLVII. Parameters of Internet Use, Abuse and Addiction: The First 90 Days of the Internet Usage Survey. Psychological Reports, 80(3), 879-882. https://doi.org/10.2466/pr0.1997.80.3.879

Brown, I. (1997). A Theoretical model of the behavioral addictions-applied to offending. In J. Hodge, M.McMurran\& C. R. Hollin (Eds.), Addicted to crime? (Vol. The Wiley series in offender rehabilitation, pp.15-63). Chichester: Wiley.

Chai, S., \& Kim, M. (2012). A socio-technical approach to knowledge contribution behavior: an empirical investigation of social networking sites users. International Journal of InformationManagement, 32(2), 118-126. https://doi.org/10.1016/j.ijinfomgt.2011.07.004

Dede, C. (2013). Connecting the dots: New technology-based models for postsecondary learning. EDUCAUSE Review, 
48(5), 33-52. Retrieved from https://er.educause.edu/ /media/files/article-downloads/erm1352.pdf

Ellison, N. B., Steinfield, C., \& Lampe, C. (2007). The benefits of Facebook friends: social capital and college students' use of online social network sites. Journal of Computer- Mediated Communication, 12(4), 1143-1168. https://doi.org/10.1111/j.1083-6101.2007.00367.x

Gao, W., Liu, Z., \& Li, J. (2017). How does social presence influence SNS addiction? A belongingness theory perspective. Computers in Human Behavior, 77, 347-355. https://doi.org/10.1016/j.chb.2017.09.002

Gonzales, A. L., \& Hancock, J. T. (2011). Mirror, mirror on my Facebook wall: Effects of exposure to facebook on self-esteem. Cyberpsychology, Behavior, and Social Networking, 14(1/2), 79-83. https://doi.org/10.1089/cyber.2009.0411

Griffiths, M. (1996). BehaviouralAddiction: An Issue for Everybody? Employee Counselling Today: The Journal of Workplace Learning, 8(3), 19-25.

Griffiths, M. (1999). Internet Addiction: Fact or Fiction? Psychologist, 12(5), 246-250.

Harzadin, T. (2012). Facebook. Retrieved from http://www.psikolo jikterapi.com / facebook-bagimliligi.html.

Hayes, A. F. (2013). Introduction to mediation, moderation, and conditional process analysis: A regression-based approach. New York, NY, US: Guilford Press.

Helliwell J., Huang H. (2013). Comparing the happiness effects or real and on-line friends. PLoS ONE, 8. https://doi.org/10.3386/w18690

Henry, S. K. (2012). On social connection in university life. About Campus: Enriching the Student Learning Experience, 16(6), 18-24. https://doi.org/10.1002/abc.20083

Jacobsen, W. C., \& Forste, R. (2011). The wired generation: Academic and social outcomes of electronic media use among university students. Cyberpsychology, Behavior, and Social Networking, 14(5), 275-280. https://doi.org/10.1089/cyber.2010.0135

James, T. L., Lowry, P. B., Wallace, L., \& Warkentin, M. (2017). The Effect of Belongingness on Obsessive-Compulsive Disorder in the Use of Online Social Networks. Journal of Management Information System, 34(2), 560-596. https://doi.org/10.1080/07421222.2017.1334496

Klingensmith, C. L. (2010). 500 Friends and Still Friending: The Relationship between Facebook and College Students' Social Experiences. Psychology Honors Project: Macalester College. Retrieved from https://digitalcommons.macalester.edu/psychology_honors/22/

Kohut, H. (1984). How does analysis cure? New York, NY: International Universities Press. https://doi.org/10.7208/chicago/9780226006147.001.0001

Leary, M. R., Kelly, K. M., Cottrell, C. A., \& Schreindorfer, L. S. (2013). Individual differences in the need to belong: Mapping the nomological network. Journal of Personality Assessment, 95(6), 1-15. https://doi.org/10.1080/00223891.2013.819511

Lee, R. M., \& Robbins, S. B. (1995). Measuring belongingness: The Social Connectedness and the Social Assurance scales. Journal of Counseling Psychology, 42(2), 232-241. https://doi.org/10.1037/0022-0167.42.2.232

Martínez-Alemán, A. M. (2014). Social media go to college. Change: The Magazine of Higher Learning, 46, 13-20. https://doi.org/10.1080/00091383.2014.867203

Maslow, A. H. (1968). Toward a psychology of being. New York: Van Nostrand.

Mazman, S. G., \& Usluel, Y.K. (2011). Gender Differences in Using Social Networks. The Turkish Online Journal of Educational Technology, 10, 133-139.

Mihailidis, P. (2014). The civic-social media disconnect: Exploring perceptions of social media for engagement in the daily life of college students. Information, Communication \& Society, 17(9), 1059-1071. https://doi.org/10.1080/1369118X.2013.877054

Moody J. (2001). Peer influence groups: identifying dense clusters in large networks. Soc. Netw., 23, 261-283. https://doi.org/10.1016/S0378-8733(01)00042-9

Palfrey, J., \& Gasser, U. (2008). Born digital: Understanding the first generation of digital natives. NewYork, NY: Basic Books.

Perrin, A. (2015, October 8). SNS usage: 2005-2015. Pew Research Center, Washington, DC. Retrieved from http://www.pewinternet.org/2015/10/08/socialnetworking-usage-2005 -2015/ 
Pittman, L. D., \& Richmond, A. (2008). University belonging, friendship quality, and psychological adjustment during the transition to college. The Journal of Experimental Education, 76(4), 343-361. https://doi.org/10.3200/JEXE.76.4.343-362

Rahman, M., \& Ahmed, O. (2018). Facebook Use, Facebook Addiction, and Mental Health of Chittagong University Studnets. Bulgerian Journal of Science and Education Policy (BJSEP), 12(2), 345-358.

Rana, M. S., Ahmed, O., \& Hossain, M. A. (2016). Facebook Addiction, Self-esteem, and Life Satisfaction of Bangladeshi Young People. Dhaka University Journal of Psychology, 40, 29-41.

Rook, K. S. (1987). Social support versus companionship: Effects on life stress, loneliness, and evaluations by others. Journal of Personality and Social Psychology, 52(6), 1132-1147. https://doi.org/10.1037/0022-3514.52.6.1132

Ryan, T., \& Xenos, S. (2011). Who uses Facebook? An investigation into the relationship between the Big Five, shyness, narcissism, loneliness, and Facebook usage. Computers in Human Behavior, 27(5), 1658-1664. https://doi.org/10.1016/j.chb.2011.02.004

Schauer, P. (2015). 5 Biggest Differences between Social Media and Social Networking. Social Media Today. Retrieved 21 March 2018 from https://www.socialmediatoday.com/social-business/peteschauer/2015-06-28/5-biggest-differences-between-socialmedia-and-social

Sheldon, K. M., Abad, N., \& Hinsch, C. (2011). A Two-Process View of Facebook Use and Relatedness Need Satisfaction: Disconnection Drives Use, and Connection Rewards It. Journal of Personality and Social Psychology, 100(4), 766-775. https://doi.org/10.1037/a0022407

Stronge, S., Osborne, D., West-Newman, T., Milojev, P., Greaves, L. M., Sibley, C. G., \& Wilson, M. S. (2015). The Facebook Feedback Hypothesis of Personality and Social Belonging. New Zealand Journal of Psychology, 44(2), 4-13. Retrieved from http://www.psychology.org.nz/wp-content/uploads/72176-NZJP-Vol-44-No-2_Facebook_.pdf

Subranian, K. R. (2017). Influence of Social Media in Interpersonal Communcation. International Journal of Scientific Progress and Research (IJSPR), 38(2), 70-75. Retrieved from http://www.ijspr.com/citations/v38n2/IJSPR_3802_2069.pdf

Summers, A. (2011). Facebook Addiction Disorder -The 6 Symptoms of FAD. Retrieved from http://www.adweek.com/digital/facebook-addiction-disorder-the-6-symptoms-of-f-a-d/

Thelwall, M. (2008). Social Networks, Gender and Friending: An Analysis of MySpace Member Profiles. Journal of the American Society for Information Science and Technology, 59(8), 1321-1330. https://doi.org/10.1002/asi.20835

Toma, C. L., \& Hancock, J. (2011). Affirming the self-online: Motives and benefits of Facebook use. Paper presented at the annual meeting of the International Communication Association. Boston, MA.

Tüfekci, Z. (2008). Gender, Social Capital And Social Network(ing) Sites: Women Bonding, Men Searching. Paper presented at the annual meeting of the American Sociological Association Annual Meeting, Sheraton Boston and the Boston Marriott Copley Place, Boston, MA, Retrieved June, 6, 2009, from http://www.allacademic.com/meta/p242696_index.html

Unger, L. S. (1984). The effects of situational variables on the subjective leisure experience. Leisure Science, 6, 291-312. Wilson, K., Fornasier, S., \& White, K. M. (2010). Psychological predictors of young adults' use of social networking sites. Cyberpsychology, Behavior, and Social Networking, 13(2), 173-177. https://doi.org/10.1080/01490408409513037

Yang, S., Liu, Y., \& Wei, J. (2016). Social capital on mobile SNS addiction: A perspective from online and offline channel integrations. Internet Research, 26(4), 982-1000. https://doi.org/10.1108/IntR-01-2015-0010

Zaremohzzabieh, Z., Samah, B. A., Omar, S. Z., Bolong, J., \& Kamarudin, N. A. (2014). Addictive Facebook Use among University Students. Asian Social Science, 10(6). https://doi.org/10.5539/ass.v10n6p107

\section{Copyrights}

Copyright for this article is retained by the author(s), with first publication rights granted to the journal.

This is an open-access article distributed under the terms and conditions of the Creative Commons Attribution license which permits unrestricted use, distribution, and reproduction in any medium, provided the original work is properly cited. 